\title{
The Effect of Interaction between Root-Knot Nematode and Sucking Insect Pests (Aphid and Whitefly) on Growth Attributes and Yield of Tomato
}

\author{
Moumita Chakraborty and Subrata Chatterjee*
}

Department of Agricultural Entomology, Bidhan Chandra Krishi Viswavidyalaya, Mohanpur, Nadia, West Bengal -741252, India

*Corresponding author

\author{
A B S T R A C T
}

K e y w o r d s
Tomato, Root-knot
nematode, Aphid,
Whitefly,
Interaction, Yield,
Growth attributes
Article Info
Accepted:
26 May 2020
Available Online:
10 June 2020

An experiment was conducted at the Central Research Farm of Bidhan Chandra Krishi Viswavidyalaya, Gayeshpur, Nadia, West Bengal to study the plant mediated interaction effect of Root knot nematode and sucking insects (aphid \& whitefly) infesting tomato plants. The whole experiment was laid out in split plot design, with three main plots of different levels of fertilizer regimes i.e. recommended doses of fertilizer, $75 \%$ of the recommended dose and $50 \%$ of the recommended dose and four sub plots of different levels of pest infestation i.e. only root knot nematode, only insects, both root knot nematode and insects and the plot in which plants were subjected to no pest infestation. The plant growth attributes such as chlorophyll SPAD value, length, fresh weight and dry weight of shoot and root and yield were recorded. The study revealed that the observations taken for plant growth attributes and yield were comparatively higher in the plots with no pest infestation and were the lowest in the plants subjected to infestation by both root knot nematode and sucking insects. The interaction effect between different fertilizer regimes and different pest infestation was significant for all plant growth attributes and yield. The populations of these pests were lower in plants infested by both as compared to the plants subjected to sole infestation of these pests.

\section{Introduction}

Tomato is the third most important vegetable crop in the world after potato and sweet potato. India ranks second in production of tomato after china with 20.70 million tonnes (Faostat, 2017). Area and production of tomato in West Bengal state is 57, 17,000 hectare and 12, 04, 43,000 tonnes (Anonymous, 2017). Tomato is a very essential component of our daily diet as it is rich in minerals, fiber and vitamin $\mathrm{A}$ and $\mathrm{B}$ which are very essential for the human health. Tomato contains lycopene which is very essential to improves skins ability to protect against ultraviolate rays (Miller et al., 2002).

Sixteen insect pests are reported in India to attack tomato from germination o till harvest (Butani, 1997). At early stage tomato plant are mainly infected by aphid (Aphis gossypii) and whitefly (Bemisia tabaci) which not only 
reduces its yield but also deteriorates the quality. Sutton (1991) reported aphids, whitefly, as major pest of vegetative stages causing 20-40\% yield loss. Meloidogyne spp. are sedentary endoparasites which is one of the major pests of tomato attacking belowground part of tomato and causing yield loss of $35 \%$ in India (Manjunatha et al., 2017).

Root-knot nematode (RKN), Meloidogyne incognita also acts as mechanical wounding agent, host modifier, rhizosphere modifier and resistant breaker; inciting or aggravating fungi and bacteria producing disease complex on severe infestations can kill the tomato plant outright (Kamran et al., 2010).

In the early 1990, were among the first to report that root feeders can significantly alter interactions between plants and aboveground herbivores (Masters et al., 1993). The impact of root feeding nematodes on aboveground insects has been less well-studied than the effects of root-feeding insects.

However, an increasing number of studies are showing that root feeding nematodes also can influence aboveground insects via their effects on the shared host plant (Bezemer et al., 2005; Kaplan et al., 2011).

The Root-knot nematode (RKN) and sucking insect pests especially aphid and whitefly have an immense effect on physical characters of the plant hence producing indirect effects on yield of tomato.

Different levels of the nutrient regimes may affect insect-nematode interaction as nutrients have a profound effect on the primary and secondary metabolites present in the plant. Keeping nutrient stress as an indicator the present study has been conducted to find out the effect of insect-nematode interaction on growth attributes and yield of tomato plant.

\section{Materials and Methods}

The field experiments were carried out at the Central Research Farm of Bidhan Chandra Krishi Viswavidyalaya, Gayeshpur, Nadia, West Bengal (Geographical location- Latitude $23^{\circ} \mathrm{N}$, Longitude $89^{\circ} \mathrm{E}$, Altitude $9.75 \mathrm{~m} \mathrm{msl}$ ). The experiment was laid out in a split plot design using tomato variety, "Heemshikhar" with three main plot treatments and four sub plot treatments. Three main treatments comprising different fertilizer doses of $\mathrm{A}_{1^{-}}$ Recommended dose of fertilizer (120:100:100), $\mathrm{A}_{2^{-}}$75\% of recommended dose of fertilizer, $\mathrm{A}_{3^{-}} 50 \%$ of recommended dose of fertilizer were in the main plots. These main plots were again sub divided into sub-plots where four treatments i.e. $\mathrm{B}_{1}$-Only root knot nematode is allowed in the plot, $\mathrm{B}_{2-}$ Only insects were allowed in the plot, $\mathrm{B}_{3}-$ Both root knot nematodes and insects were allowed in the plot, $\mathrm{B}_{4^{-}}$No pests were allowed to infest the crop with five replications were adopted.

The plot size of $1.5 \mathrm{~m}$ by $1.5 \mathrm{~m}\left(2.25 \mathrm{~m}^{2}\right)$ with row to row distance of $60 \mathrm{~cm}$ and plant to plant distance $50 \mathrm{~cm}$ was used. The plots with only root knot nematode attack and no pest attack were kept within the mesh to avoid insect attack. The nursery bed was sterilized by drenching with $4 \%$ formaldehyde at 15 days prior to sowing of tomato seeds to get the seedlings free from nematodes and other plant pathogens. Sterilization of the main field soil was done with $4 \%$ formalin, one month before transplanting tomato seedlings in the plots where either no pests was allowed or only insects were allowed to infest the crop. The sterilization process was carried out along with the FYM so as to prevent the infestation of the nematodes and other plant pathogens. The soil was drenched with $4 \%$ Formaldehyde and then covered with polythene sheet for 7 days. After 7 days the soil was pulverized and kept open to remove 
the toxic gases of formaldehyde. The plants under control and the plants which were subjected to insect attack were grown in pots with a diameter of $25 \mathrm{~cm}$. Recommended package of practices were adopted to raise the crop and irrigation was given as and when required.

The plant growth attributes involved chlorophyll SPAD value, length, fresh weight and dry weight of shoot and root taken during peak growth stage. The Chlorophyll SPAD (soil plant analysis development) value reading of upper, middle and lower leaf was taken with the help of SPAD meter. The SPAD meter gives a SPAD value which is the reading pertaining to the absorption of sun light by the photosynthetic pigment. This reading is directly proportional to the chlorophyll pigment content of the leaves. We simply clamped the meter over leafy tissue, and receive an indexed chlorophyll content reading. Yield of matured fruit was estimated from each and every plot and expressed in $\mathrm{Kg} / \mathrm{ha}$. Data analysis was done using Real Statistics' Split -plot ANOVA data analysis tool of Excel.

\section{Results and Discussion}

\section{Chlorophyll SPAD value}

The observation taken with the help of SPAD meter revealed that the SPAD value of the leaves of plants in the control plot was highest followed respectively by the plants harboured only insects and the plants infested by only root knot nematodes. The lowest SPAD value was recorded in the plants which were subjected to infestation by both root knot nematodes and insects in all the nodal leaves present in the plants irrespective of the nutritional regimes. These observations can be inferred from (Table 1 and Fig. 1). Different doses of fertilizer had no significant effect for upper and lower leaf but different types of pest infestation had significantly influenced chlorophyll SPAD value for all types of leaves. The interaction effect of different fertilizer regimes and pest infestation was worked out in split-plot technique and it was found to be significant in all the nodal leaves under nutrient regimes. Root-feeding nematodes can positively or negatively affect shoot herbivorous insects, and vice versa. As herbivore often elicits systemic changes in plant traits, indirect interactions via induced plant responses may be a pervasive feature structuring herbivore communities (Van Dam et al., 2003; Bezemer \& Van Dam, 2005; Kaplan et al., 2008).

\section{Fresh weight, dry weight and length of shoot}

The data recorded for these parameters is presented in (Table 2 and Fig. 2). Fresh \& dry weight and length of shoot is significantly high for the plots where no insects and nematode infestation had occurred. With regard to the parameter fresh and dry weight no significant difference has been observed among the plots infested by only RKN or only insects or both RKN \& insects. In most of cases shoot length of plots with only $\mathrm{RKN}$ is statistically at par with shoot length of the plots with only insects.

Regarding the interaction effect of different doses and types of pest infestation it was found that all of these parameters were influenced significantly by the said interaction effect. Different doses of fertilizer had no significant effect on length of shoot but all the parameters were found statistically significant in different types of pest infestation. Perhaps the most pervasive opportunity for two 'separate' communities to influence one another occurs at the soil - air interface where plants serve as a conduit linking the dynamics of above and belowground biota (Van der Putten et al., 2001; Wardle et al., 2004). 
Table.1 Chlorophyll SPAD VALUE of fully matured leaves in the plots under different nutrient regime

\begin{tabular}{|c|c|c|c|c|c|c|c|c|c|}
\hline \multirow[b]{2}{*}{ Treatments } & \multicolumn{3}{|c|}{ UPPER LEAF } & \multicolumn{3}{|c|}{ MIDDLE LEAF } & \multicolumn{3}{|c|}{ LOWER LEAF } \\
\hline & $\begin{array}{c}\text { Recommended } \\
\text { dose of } \\
\text { fertilizers } \\
\mathbf{A}_{\mathbf{1}}\end{array}$ & $\begin{array}{c}75 \% \text { of } \\
\text { recommended } \\
\text { dose of } \\
\text { fertilizers } \\
\mathbf{A}_{2}\end{array}$ & $\begin{array}{c}50 \% \text { of } \\
\text { recommended } \\
\text { dose of } \\
\text { fertilizers } \\
\mathbf{A}_{\mathbf{3}}\end{array}$ & $\begin{array}{c}\text { Recommended } \\
\text { dose of } \\
\text { fertilizers } \\
\mathbf{A}_{1}\end{array}$ & $\begin{array}{c}75 \% \text { of } \\
\text { recommended } \\
\text { dose of } \\
\text { fertilizers } \\
\mathbf{A}_{\mathbf{2}}\end{array}$ & $\begin{array}{c}50 \% \text { of } \\
\text { recommended } \\
\text { dose of } \\
\text { fertilizers } \\
\mathbf{A}_{\mathbf{3}}\end{array}$ & $\begin{array}{c}\text { Recommended } \\
\text { dose of } \\
\text { fertilizers } \\
\mathbf{A}_{\mathbf{1}}\end{array}$ & $\begin{array}{c}75 \% \text { of } \\
\text { recommended } \\
\text { dose of } \\
\text { fertilizers } \\
\mathbf{A}_{2}\end{array}$ & $\begin{array}{c}50 \% \text { of } \\
\text { recommended } \\
\text { dose of } \\
\text { fertilizers } \\
\mathbf{A}_{\mathbf{3}}\end{array}$ \\
\hline $\begin{array}{c}\text { B }_{1} \text {-Only } \\
\text { RKN }\end{array}$ & $\begin{array}{l}46.03 \\
(6.82)\end{array}$ & $\begin{array}{l}47.20 \\
(6.91)\end{array}$ & $\begin{array}{l}57.02 \\
(7.58)\end{array}$ & $\begin{array}{l}49.08 \\
(7.04)\end{array}$ & $\begin{array}{l}48.65 \\
(7.01)\end{array}$ & $\begin{array}{l}54.30 \\
(7.40)\end{array}$ & $\begin{array}{l}45.31 \\
(6.77)\end{array}$ & $\begin{array}{l}49.43 \\
(7.07)\end{array}$ & $\begin{array}{l}46.50 \\
(6.86)\end{array}$ \\
\hline $\begin{array}{l}\mathbf{B}_{2} \text {-Only } \\
\text { Insects }\end{array}$ & $\begin{array}{l}64.29 \\
(8.05)\end{array}$ & $\begin{array}{l}56.34 \\
(7.54)\end{array}$ & $\begin{array}{l}55.75 \\
(7.50)\end{array}$ & $\begin{array}{l}57.58 \\
(7.62)\end{array}$ & $\begin{array}{l}64.91 \\
(8.09)\end{array}$ & $\begin{array}{l}51.08 \\
(7.18)\end{array}$ & $\begin{array}{l}48.02 \\
(6.97)\end{array}$ & $\begin{array}{l}48.55 \\
(7.00)\end{array}$ & $\begin{array}{l}44.48 \\
(6.71)\end{array}$ \\
\hline $\begin{array}{c}\text { B }_{\mathbf{3}} \text {-Both } \\
\text { RKN and } \\
\text { Insects }\end{array}$ & $\begin{array}{l}41.25 \\
(6.46)\end{array}$ & $\begin{array}{l}46.04 \\
(6.82)\end{array}$ & $\begin{array}{l}40.34 \\
(6.39)\end{array}$ & $\begin{array}{l}45.71 \\
(6.80)\end{array}$ & $\begin{array}{l}47.07 \\
(6.90)\end{array}$ & $\begin{array}{l}47.80 \\
(6.95)\end{array}$ & $\begin{array}{l}43.18 \\
(6.61)\end{array}$ & $\begin{array}{l}41.48 \\
(6.48)\end{array}$ & $\begin{array}{l}47.13 \\
(6.90)\end{array}$ \\
\hline $\begin{array}{c}\mathrm{B}_{4} \text {-no } \mathrm{RKN} \\
\text { \& pest }\end{array}$ & $\begin{array}{l}67.18 \\
(8.23)\end{array}$ & $\begin{array}{l}65.33 \\
(8.11)\end{array}$ & $\begin{array}{l}64.20 \\
(8.04)\end{array}$ & $\begin{array}{l}66.22 \\
(8.17)\end{array}$ & $\begin{array}{l}69.94 \\
(8.39)\end{array}$ & $\begin{array}{l}67.20 \\
(8.23)\end{array}$ & $\begin{array}{l}62.41 \\
(7.93)\end{array}$ & $\begin{array}{l}65.87 \\
(8.15)\end{array}$ & $\begin{array}{l}64.18 \\
(8.04)\end{array}$ \\
\hline & & SEm \pm & $\operatorname{CD}(5 \%)$ & & SEm \pm & $\operatorname{CD}(5 \%)$ & & SEm \pm & $\operatorname{CD}(5 \%)$ \\
\hline A factor & NS & 1.33 & 4.35 & $\mathrm{~S}$ & 0.69 & 2.26 & NS & 0.49 & 1.58 \\
\hline B factor & $\mathrm{S}$ & 1.06 & 3.05 & $\mathrm{~S}$ & 0.90 & 2.57 & $\mathrm{~S}$ & 0.92 & 2.62 \\
\hline AXB factor & S & 2.08 & 5.96 & $\mathrm{~S}$ & 1.51 & 4.34 & $\mathrm{~S}$ & 1.46 & 4.18 \\
\hline BXA factor & $\mathrm{S}$ & 1.84 & 5.21 & $\mathrm{~S}$ & 1.55 & 4.39 & $\mathrm{~S}$ & 1.59 & 4.49 \\
\hline
\end{tabular}

*Values in the parentheses [SQRT (original value+0.5)] are root transformed values 
Table.2 Fresh weight, dry weight and length of shoot of the plants under different treatments in different nutrient regimes

\begin{tabular}{|c|c|c|c|c|c|c|c|c|c|}
\hline \multirow[b]{2}{*}{ Treatments } & \multicolumn{3}{|c|}{ Fresh weight of shoot (g) } & \multicolumn{3}{|c|}{ Dry weight of shoot (g) } & \multicolumn{3}{|c|}{ Length of shoot (cm) } \\
\hline & $\begin{array}{c}\text { Recommended } \\
\text { dose of } \\
\text { fertilizers } \\
\mathbf{A}_{\mathbf{1}}\end{array}$ & $\begin{array}{c}75 \% \text { of } \\
\text { recommended } \\
\text { dose of } \\
\text { fertilizers } \\
\mathbf{A}_{2}\end{array}$ & $\begin{array}{c}50 \% \text { of } \\
\text { recommended } \\
\text { dose of } \\
\text { fertilizers } \\
\mathbf{A}_{3}\end{array}$ & $\begin{array}{c}\text { Recommende } \\
\text { d dose of } \\
\text { fertilizers } \\
\mathbf{A}_{1}\end{array}$ & $\begin{array}{c}75 \% \text { of } \\
\text { recommended } \\
\text { dose of } \\
\text { fertilizers } \\
\mathbf{A}_{2}\end{array}$ & $\begin{array}{c}50 \% \text { of } \\
\text { recommended } \\
\text { dose of fertilizers } \\
\mathbf{A}_{3}\end{array}$ & $\begin{array}{c}\text { Recommende } \\
\text { d dose of } \\
\text { fertilizers } \\
\mathbf{A}_{1}\end{array}$ & $\begin{array}{l}75 \% \text { of } \\
\text { recommende } \\
d \text { dose of } \\
\text { fertilizers } \mathbf{A}_{2}\end{array}$ & $\begin{array}{c}50 \% \text { of } \\
\text { recommended } \\
\text { dose of } \\
\text { fertilizers } \\
\mathbf{A}_{\mathbf{3}}\end{array}$ \\
\hline B $_{1}$-Only RKN & 160.80 & 133.00 & 123.80 & 35.60 & 40.40 & 33.00 & 88.08 & 83.17 & 86.16 \\
\hline $\mathbf{B}_{2}$-Only Insects & 148.80 & 121.20 & 126.80 & 27.40 & 27.60 & 22.40 & 85.01 & 80.75 & 78.08 \\
\hline$B_{3}$-Both RKN and Insects & 136.80 & 120.60 & 111.20 & 21.20 & 28.80 & 27.40 & 67.24 & 65.05 & 73.48 \\
\hline$B_{4^{-}}$No insects and RKN & 199.40 & 318.40 & 159.60 & 63.40 & 55.40 & 43.00 & 92.95 & 95.88 & 87.61 \\
\hline & & SEm \pm & $\operatorname{CD}(5 \%)$ & & SEm \pm & $\operatorname{CD}(5 \%)$ & & SEm \pm & $\operatorname{CD}(5 \%)$ \\
\hline A factor & $\mathrm{S}$ & 5.41 & 17.63 & $\mathrm{~S}$ & 0.72 & 2.34 & NS & 1.05 & 3.43 \\
\hline B factor & $S$ & 4.82 & 13.82 & $\mathrm{~S}$ & 1.36 & 3.90 & $\mathrm{~S}$ & 0.93 & 2.66 \\
\hline AXB factor & S & 9.02 & 25.88 & $\mathrm{~S}$ & 2.16 & 6.20 & S & 1.74 & 5.00 \\
\hline BXA factor & $\mathrm{S}$ & 8.34 & 23.61 & $\mathrm{~S}$ & 2.36 & 6.66 & S & 1.61 & 4.55 \\
\hline
\end{tabular}

Table.3 Fresh weight, dry weight and length of root of the plants under different treatments in different nutrient regimes

\begin{tabular}{|c|c|c|c|c|c|c|c|c|c|}
\hline \multirow[t]{2}{*}{ Treatments } & \multicolumn{3}{|c|}{ Fresh weight (g) } & \multicolumn{3}{|c|}{ Dry weight (g) } & \multicolumn{3}{|c|}{ Length (cm) } \\
\hline & $\begin{array}{c}\text { Recommende } \\
\text { d Doses Of } \\
\text { Fertilizer } \\
\mathbf{A}_{\mathbf{1}}\end{array}$ & $\begin{array}{c}75 \% \text { of } \\
\text { Recommended } \\
\text { Doses Of } \\
\text { Fertilizer } \\
\mathbf{A}_{\mathbf{2}}\end{array}$ & $\begin{array}{c}50 \% \text { of } \\
\text { Recommended } \\
\text { Doses Of } \\
\text { Fertilizer } \\
\mathbf{A}_{\mathbf{3}}\end{array}$ & $\begin{array}{c}\text { Recommended } \\
\text { Doses Of } \\
\text { Fertilizer } \\
\mathbf{A}_{\mathbf{1}}\end{array}$ & $\begin{array}{c}75 \% \text { of } \\
\text { Recommended } \\
\text { Doses Of } \\
\text { Fertilizer } \\
\mathbf{A}_{\mathbf{2}}\end{array}$ & $\begin{array}{c}50 \% \text { of } \\
\text { Recommended } \\
\text { Doses Of } \\
\text { Fertilizer } \\
\mathbf{A}_{\mathbf{3}}\end{array}$ & $\begin{array}{c}\text { Recommended } \\
\text { Doses Of } \\
\text { Fertilizer } \\
\mathbf{A}_{\mathbf{1}}\end{array}$ & $\begin{array}{c}75 \% \text { of } \\
\text { Recommended } \\
\text { Doses Of } \\
\text { Fertilizer } \\
\mathbf{A}_{\mathbf{2}}\end{array}$ & $\begin{array}{c}50 \% \text { of } \\
\text { Recommended } \\
\text { Doses Of } \\
\text { Fertilizer } \\
\mathbf{A}_{\mathbf{3}}\end{array}$ \\
\hline B $_{1}$-Only RKN & 17.08 & 15.19 & 11.91 & 3.34 & 2.51 & 2.07 & 20.93 & 19.75 & 22.14 \\
\hline $\mathbf{B}_{2}$-Only Insects & 12.34 & 13.84 & 13.36 & 2.97 & 3.18 & 3.03 & 17.86 & 19.35 & 15.06 \\
\hline $\begin{array}{l}B_{3} \text {-Both RKN } \\
\text { and Insects }\end{array}$ & 13.11 & 13.10 & 17.81 & 2.12 & 4.02 & 2.38 & 19.14 & 21.56 & 17.04 \\
\hline \multirow[t]{2}{*}{$\mathbf{B}_{4}$-Control } & 27.26 & 16.04 & 10.42 & 8.98 & 8.18 & 5.15 & 28.47 & 14.83 & 16.00 \\
\hline & & SEm \pm & $\operatorname{CD}(5 \%)$ & & SEm \pm & $\operatorname{CD}(5 \%)$ & & SEm \pm & $\operatorname{CD}(5 \%)$ \\
\hline A factor & $\mathrm{S}$ & 0.48 & 1.55 & $\mathrm{~S}$ & 0.22 & 0.72 & $\mathrm{~S}$ & 0.47 & 1.52 \\
\hline B factor & $\mathrm{S}$ & 0.59 & 1.69 & $\mathrm{~S}$ & 0.24 & 0.70 & $\mathrm{~S}$ & 0.33 & 0.96 \\
\hline AXB factor & $\mathrm{S}$ & 1.00 & 2.88 & $\mathrm{~S}$ & 0.43 & 1.23 & $\mathrm{~S}$ & 0.68 & 1.96 \\
\hline BXA factor & S & 1.02 & 2.89 & $\mathrm{~S}$ & 0.42 & 1.20 & $\mathrm{~S}$ & 0.58 & 1.63 \\
\hline
\end{tabular}


Table.4 Yield of the tomato plants in different nutrient regimes under different treatments

\begin{tabular}{|c|c|c|c|}
\hline \multirow[t]{2}{*}{ Treatments } & \multicolumn{3}{|c|}{ Yield at different doses of fertilizer $(\mathrm{Kg} / \mathrm{ha})$} \\
\hline & $\begin{array}{c}\text { Recommended doses of } \\
\text { fertilizer } \\
\mathbf{A}_{\mathbf{1}}\end{array}$ & $\begin{array}{c}75 \% \text { of recommended doses } \\
\text { of fertilizer } \\
\mathbf{A}_{2}\end{array}$ & $\begin{array}{c}50 \% \text { of recommended } \\
\text { doses of fertilizer } \\
\mathbf{A}_{\mathbf{3}}\end{array}$ \\
\hline B $_{1}$-Only RKN & 27990 & 26100 & 17900 \\
\hline $\mathrm{B}_{2}$-Only Insects & 24800 & 24790 & 24650 \\
\hline $\begin{array}{l}\text { B }{ }_{3} \text {-Both RKN and } \\
\text { Insects }\end{array}$ & 20570 & 25010 & 16550 \\
\hline $\begin{array}{l}\text { B } 4 \text {-No RKN \& } \\
\text { insects }\end{array}$ & 32000 & 32570 & 28120 \\
\hline & & SEm \pm & CD (5\%) \\
\hline A factor & $\mathrm{S}$ & 698.37 & 2277.51 \\
\hline B factor & $\mathrm{S}$ & 683.83 & 1961.32 \\
\hline AXB factor & $\mathrm{S}$ & 1240.91 & 3559.13 \\
\hline BXA factor & $\mathrm{S}$ & 1184.42 & 3351.72 \\
\hline
\end{tabular}

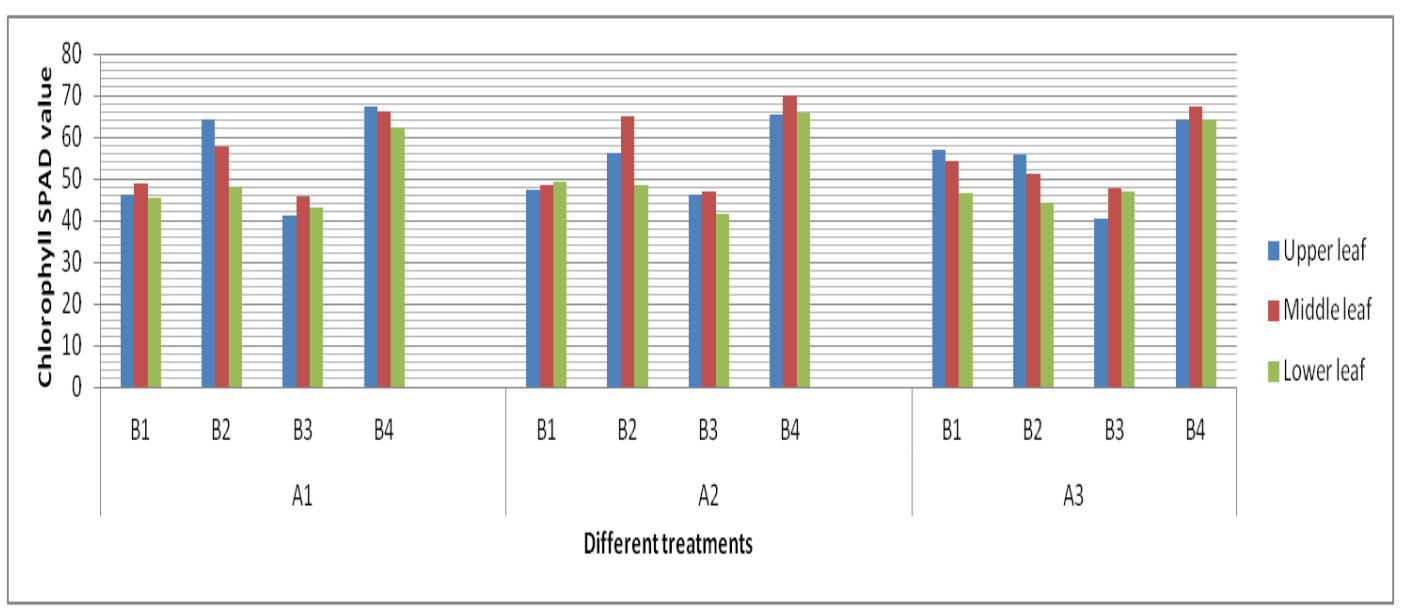

Fig.1 Chlorophyll SPAD value of upper, middle and lower leaves of tomato plants under different treatments

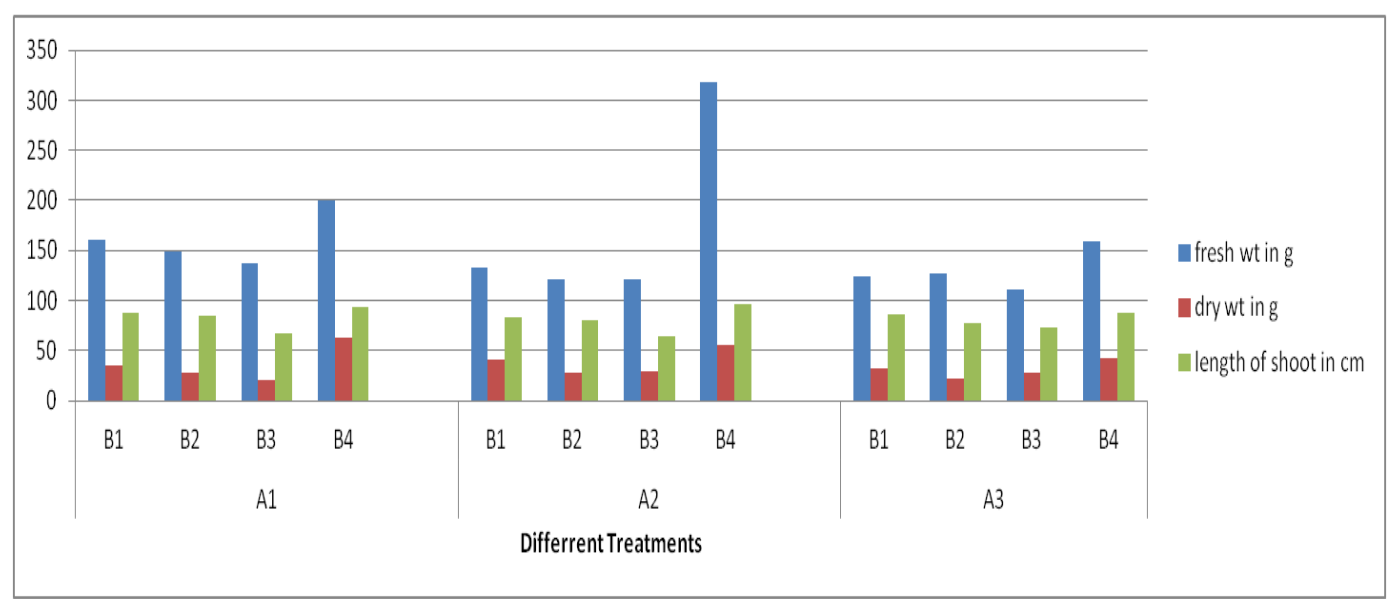

Fig.2 Fresh \& dry weight and length of shoot of tomato plants under different treatments 


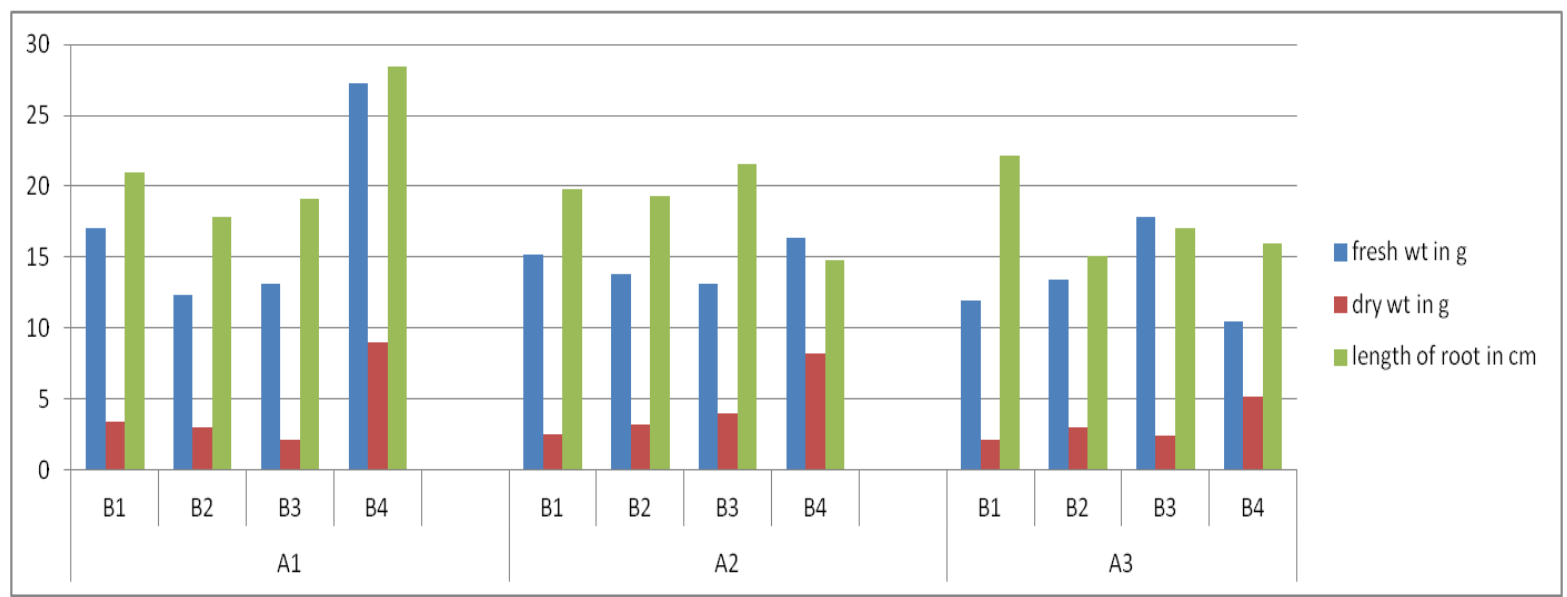

Fig.3 Fresh weight \& dry weight and length of root of tomato plants under different treatments

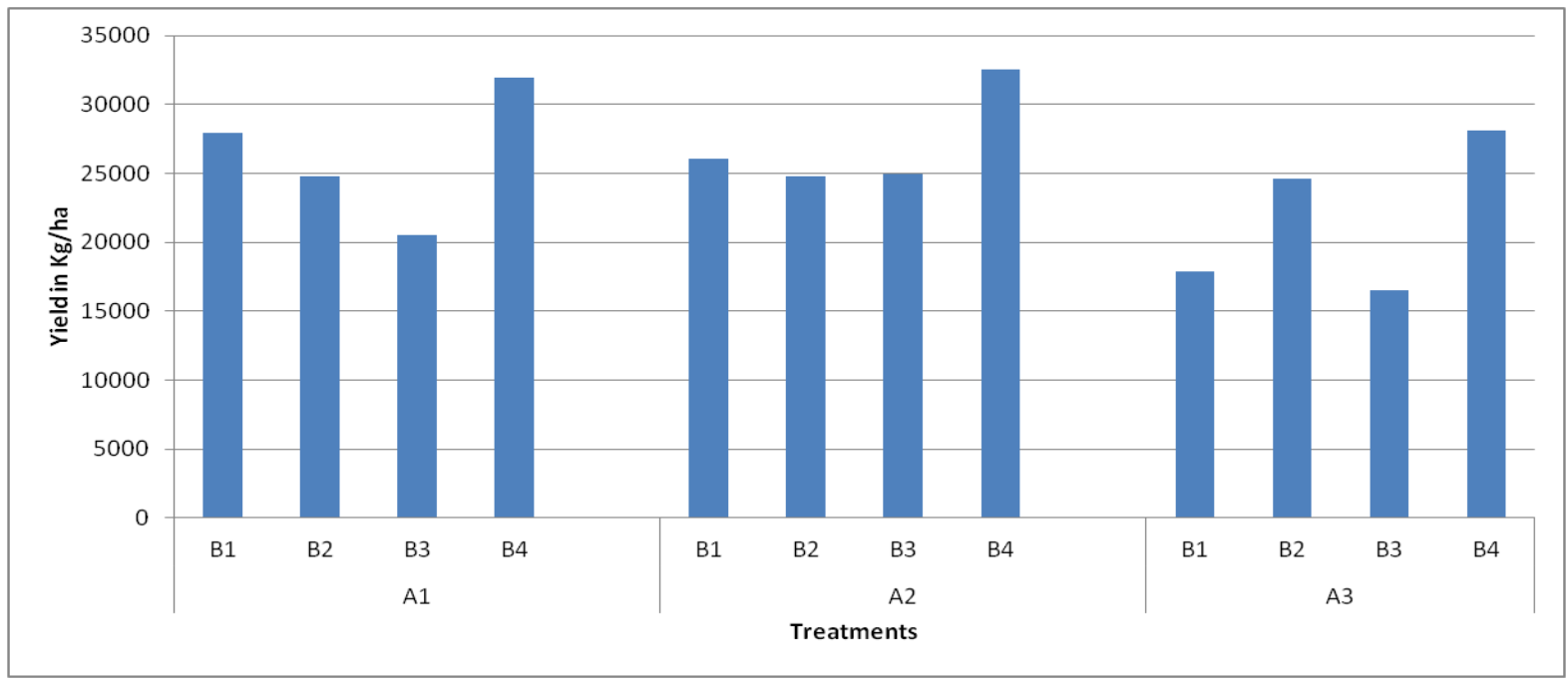

Fig.4 Yield of tomato plants under different treatments

Fresh weight, dry weight and length of root

With regard to fresh weight of root maximum value observed for plots where no insects \& pest infestation had occurred except the plot with $50 \%$ recommended dose of fertilizer, here maximum value was observed for plots infested by both insects and nematodes.

In most cases there was significant difference between plots infested with only insects and both RKN \& insects. In case of dry weight of root the plots with no pest attack had showed best performance. In most of cases there was no significant difference among treatments infested by only RKN , only insects and both
RKN \& insects. Length of root at recommended dose of fertilizer is the maximum for plots with no pest attack but it is maximum for plots infested with both RKN and insects at $75 \%$ recommended dose of fertilizer. At 50\% recommended dose root length is maximum for plots infested with only RKN. All the data are presented on (Table 3 and Fig. 3).

All of the attributes were found statistically significant in different doses of fertilizer as well as different types of pest infestation. Interaction effect of different doses and types of pest infestation was found significant for all root attributes. 
It can be concluded that the sucking of the plant sap by the nematodes and phloem feeding by the insects played a major role in their affecting the growth attributes and This awareness of plant-mediated above belowground interactions has brought a new level of complexity to the field of plant-insect ecology (Van der Putten et al., 2001; Bardgett and Wardle, 2003; Wardle et al., 2004).

\section{Yield (Kg/ha)}

Irrespective of the nutrient regimes Yield of plots with no pest attack had shown the maximum yield. At recommended dose \& $50 \%$ dose of fertilizer minimum yield was observed for the plots infested with both RKN \& insects but at $75 \%$ doses of fertilizer minimum yield was for the plots infested with only insects (Table 4 and Fig. 4). The interaction of different dose of fertilizer and types of pest infestation had pronounced effect on yield of tomato plant. Higher value was obtained from treatment combination of $\mathrm{A}_{2} \mathrm{~B}_{4}$ i.e. no pest attack with $75 \%$ of rec. Dose of fertilizer and the lowest value was recorded from $\mathrm{A}_{3} \mathrm{~B}_{3}$ i.e. both $\mathrm{RKN}$ and insects with $50 \%$ of rec. dose of fertilizers.

Despite adequate availability of nutrients under recommended dose of fertilizer, plants infested by both root knot nematodes and sucking pests the observations on chlorophyll SPAD value, length, fresh weight and dry weight of shoot and root were lower as compared to the plants without any infestation of these pests. This could have happened due to plant mediated interaction between these two spatially separated organisms.

\section{References}

Anonymous., 2017. Ministry of Agriculture, Government of India, or www.nhb.gov.in. National Horticulture Board Database, 2015-2016.
Bardgett, R. D., Wardle, D. A. 2003. Herbivore-mediated linkages between above ground and below ground communities. Ecology. 84: 2258-2268.

Bezemer, T. M., and Van Dam, N. M. 2005. Linking aboveground and belowground interactions via induced plant defences. Trends in Ecological Evolution. 20: 617-624.

Bezemer, T. M., Van Dam, N. M. 2005. Linking aboveground and belowground interactions via induced plant defenses. Trends in Ecological Evolution. 20: 617-624

Butani, D.K., 1977. Insect pest of vegetablestomato. Pesticides. 11: 33-36.

http://www.fao.org. 15 May, 2017.

Kamran, M., S.A. Anwar, N. Javed, S.A. Khan, Sahi, G.M. 2010. Incidence of root knot nematodes on tomato in Sargodha, Punjab, Pakistan. Pakistan Journal of Nematology. 28: 253-262.

Kaplan, I., R. Halitschke, A. Kessler, B. J. Rehill, S. Sardanelli, Denno, R. F. 2008. Physiological integration of roots and shoots in plant defense strategies links above-and below ground herbivory. Ecological Letter. 11: 841-851.

Kaplan, I., S. Sardanelli, B. J. Rehill, Denno, R. F. 2011. Toward a mechanistic understanding of competition in vascular feeding herbivores: an empirical test of the sink competition hypothesis. Oecologia. 166: 627-636.

Manjunatha, T.G., A.B. Rai, Singh B. 2017. Root Knot Nematode: A Threat to Vegetable Production and its Management. IIVR Technical Bulletien No. 76, IIVR, Varanasi. 32.

Masters, G.J., V.K. Brown, Gange, A.C. 1993. Plant mediated interactions between above ground and belowground insect herbivores. Oikos. 66(1): 148-151.

Miller, E.C., C.W. Hadley, S.J. Schwarts, J.W. Erdman, T.M.W. Boileau, Clinton, 
S.K. 2002. Lycopene, tomato products and prostate cancer prevention. Have we established causality?. Pure and Applied Chemistry. 74 (8): 1435-1441.

Sutton, A., 1991. Tomato Vegetable Market Development Team, CIBA-GEIGY. AG 6.82 Basel, January. 6-60.

Van Dam, N. M., J. A. Harvey, F. L. Wäckers, T. M Bezemer, W. H. Van Der Putten, Vet, L. E. M. 2003. Interactions between above ground and belowground induced responses against Phytophages. Basic and Applied Ecology. 4: 63-77.
Van Der Putten, W. H., L. E. M. Vet, J. A. Harvey, Wäckers, F. L. 2001. Linking above and below ground multitrophic interactions of plants, herbivores, pathogens, and their antagonists. Trends in Ecology and Evolution. 16: 547-54.

Wardle, D. A., R. D. Bardgett, J. N. Klironomos, H. Setala, W. H. Vander Putten, Wall, D. H. 2004. Ecological linkages between above ground and below ground biota. Science. 304: $1629-1633$.

\section{How to cite this article:}

Moumita Chakraborty and Subrata Chatterjee. 2020. The Effect of Interaction between RootKnot Nematode and Sucking Insect Pests (Aphid and Whitefly) on Growth Attributes and Yield of Tomato. Int.J.Curr.Microbiol.App.Sci. 9(06): 3700-3708.

doi: https://doi.org/10.20546/ijcmas.2020.906.437 